\title{
Le débat sur le 'Roman de la Rose', traduit en français moderne par Virginie Greene
}

\section{Antonella Amatuzzi}

\section{(2) OpenEdition}

1 Journals

\section{Édition électronique}

URL : http://journals.openedition.org/studifrancesi/9443

DOI : 10.4000/studifrancesi.9443

ISSN : 2427-5856

Éditeur

Rosenberg \& Sellier

\section{Édition imprimée}

Date de publication : 1 décembre 2007

Pagination : 634

ISSN : 0039-2944

\section{Référence électronique}

Antonella Amatuzzi, « Le débat sur le 'Roman de la Rose', traduit en français moderne par Virginie

Greene », Studi Francesi [En ligne], 153 (LI | III) | 2007, mis en ligne le 30 novembre 2015, consulté le 16 janvier 2021. URL : http://journals.openedition.org/studifrancesi/9443 ; DOI : https://doi.org/10.4000/ studifrancesi.9443

Ce document a été généré automatiquement le 16 janvier 2021.

\section{(c) 9 (i) $\Theta$}

Studi Francesi è distribuita con Licenza Creative Commons Attribuzione - Non commerciale - Non opere derivate 4.0 Internazionale. 


\title{
Le débat sur le 'Roman de la Rose', traduit en français moderne par Virginie Greene
}

\author{
Antonella Amatuzzi
}

\section{RÉFÉRENCE}

Le débat sur le 'Roman de la Rose', traduit en français moderne par Virginie GREENE, Paris, Honoré Champion, 2006 («Traductions des classiques du Moyen Âge», 76), pp. 348.

1 Il s'agit de la traduction en français moderne des pièces relatives au débat sur le Roman de la Rose à partir de l'édition fournie par Eric Hicks en 1977. Cet éminent médiéviste avait voulu réunir plusieurs documents (des lettres, essentiellement) témoignant de la première querelle littéraire française: entre 1401 et 1405 Jean de Montreuil, Gontier Col, Pierre Col, Jean Gerson et Christine de Pizan s'expriment à propos de la qualité morale et littéraire du Roman de la Rose.

2 La présente édition n'est pas uniquement destinée à des spécialistes de littérature médiévale. Elle vise un public plus vaste et pour cette raison Virginie Greene, tout en se basant sur l'apparat de notes de Hicks, le simplifie. Elle ajoute en revanche des informations d'ordre général, développe les citations (en accompagnant celles en latin d'une traduction française) et met à jour la bibliographie.

Dans son introduction elle retrace l'histoire du débat et précise la position de chacun des participants à la querelle. Christine de Pizan et Jean Gerson condamnent l'obscénité et la misogynie de certains passages du Roman alors que Jean de Montreuil et les frères Col défendent Jean de Meung.

Elle rappelle aussi que ce débat n'a cessé d'intéresser la critique et qu'il est encore ouvert de nos jours. Si à la fin du xixe siècle et jusqu'avant la deuxième guerre mondiale des savants comme Gaston Paris, Gustave Lanson et Alfred Coville voyaient dans les frères $\mathrm{Col}$ et Jean de Montreuil des humanistes, précurseurs de la Renaissance, et dans 
Gerson une personnalité trop soucieuse de défendre la bonne doctrine chrétienne, aujourd'hui Christine et Gerson ne peuvent plus être considérés des poètes mineurs et «la question des femmes, de leur rôle et de leur place dans la société est revenue au centre du débat sur le débat» (pp. 22-23). 